\title{
PERFIL
}

\section{PAULO ELIEZER FERRI DE BARROS (1946-2006)}

ARI REHFELD

Muito difícil falar sobre o Paulo. Ele era muito próximo embora, ultimamente, não nos víssemos com tanta freqüência. Ao falar dele temo trair uma grande cumplicidade que tínhamos.

Tenho claro que não conseguirei, com toda a plenitude, expressar o que Paulo significava para mim.

Sinto-me paralisado. Quando aceitei escrever, em um telefonema rápido, não imaginei tal grau de dificuldade. Imagino-me contando a ele desta minha dificuldade, e ele colocando a mão em meu peito, olhando bem fixamente em meus olhos, sorrindo, falando num tom bem firme: "Começa, começa e vai!"

Incentivava a escrever. Ele tinha o dom. Fala muito precisa e que tinha a capacidade de tocar a alma a fundo, promovendo um turbilhão emocional em quem o lesse ou, maior ainda, talvez, em quem o escutasse.

Fala de sábio, convicto, sério, pausado, de quem refletiu muito. Fala de amante, com leveza, acariciando e também pegando forte... Fala de poeta, com o rigor e a precisão de cada palavra. Fala de prosador, que sabendo envolver e segurar com um suspense expectante, até um desenlace imprevisível.

Era capaz de integrar estas diferentes falas de modo a provocar, sempre, a sensação de "quero mais..."

Fui seu aluno em workshop vivencial, parceiro em outros, encaminhei alguns ex-pacientes a ele e supervisionei terapeutas, seus clientes. Pude presenciar um grande terapeuta. Sabia realmente ouvir, ver, compreender e responder ao que o outro necessitava. Às vezes o fazia de modo um tanto brusco, procurando sacudir, revolver, em busca de uma nova figura. Preciso como um bom cirurgião. Tinha foco, sabia o que queria, não gastava palavras à toa. De quando em quando, contribuía, em geral ao final de um trabalho, com um depoimento pessoal, onde descrevia como convivia com tal dificuldade.

Tenho claro para mim que estas suas capacidades derivavam de uma compreensão de si próprio muito grande. Freqüentemente retirava-se do convívio quotidiano, seja através de uma meditação silenciosa, de alguns minutos, seja por uma pescaria de muitos dias, ou uma ida ao seu sítio ou à praia... e voltava renovado, rejuvenescido e com muito material que, de modo alquímico, processava com os mais próximos. Coisa de bruxo mesmo.

Introvertido, com a sabedoria de um velho, embora não tivesse tanta idade, era um lobo solitário, não preso a nenhum agrupamento, “máfia” ou “igrejinha”, e sempre bem-vindo a todas elas... Tinha o passe livre. 
Trocávamos muitas estórias. Colecionávamos. Uma vez deu-me cópia de uma que acabara de escrever: "Bruxas, e como desfazê-las". Gostei muito! Vi nela, mas nunca soube se foi realmente sua intenção, a melhor descrição que eu já havia visto do processo terapêutico, "de tornar uma mulher mais mulher, feminina". Passei a lê-la em minhas aulas, praticamente em todos os cursos, por muitos anos, até agora, e assim aproveitava para, a meu modo, apresentar Paulo aos meus alunos. E, quando ele soube disso, muito tempo depois, ao publicá-la, mencionou este fato em uma nota.

Paulo foi um dos introdutores da Gestalt-Terapia no Brasil. No início dos anos 1970 foi aos Estados Unidos e voltou cheio de energia, e com muito material. Distribuiu-o e, como um bom professor, entusiasmou a todos com as novas idéias. Nos Estados Unidos fez um treinamento intensivo, em Gestalt-Terapia, com John O. Stevens, no Esalen Institute, e também lá fez Bioenergética com Alan Swarts e professores do Radix Institute.

Ele teve o privilégio de fazer grupo de estudos e supervisão com o professor Pethor Sandor (1972-1974), e também com o professor Sólon Spanoudis (1974-1976). Estudou com o professor José Ângelo Gaiarsa em abordagem corporal, fez treinamento intensivo com Robert L. Martin e seminários semanais com o professor Zeljko Loparic.

Foi diretor da coleção "Novas Buscas em Psicoterapia", pela editora Summus, com 29 títulos publicados. Ele selecionou os títulos, fez o contato com as editoras estrangeiras e fez a revisão científica das traduções. Mais tarde, no Conselho Editorial, participou da publicação de mais onze títulos. É importante enfatizar que esta coleção foi a primeira, e a mais importante na literatura da GestaltTerapia em português, e, através dela, a Gestalt-Terapia se difundiu.

Em 1985 ele organizou e publicou, pela mesma editora Summus, com Ieda Porchat, "Ser Terapeuta". Em 1994 publicou pela mesma editora, "Narciso, a Bruxa, o Terapeuta Elefante e outras Estórias Psi” e, em 2006, “Amor e Ética”.

Paulo foi professor da Faculdade de Psicologia da PUC-SP, da OMEC e da Universidade de Lorena, sendo nelas responsável, por muitos anos, pela cadeira de “Teorias e Técnicas Psicoterápicas”. Foi professor convidado no curso de GestaltTerapia do Instituto Sedes Sapientiae, no curso de Pós-Graduação em Psicologia da PUC-SP e no Instituto de Gestalt de São Paulo. Proferiu um sem-número de palestras e conferências, e conduziu Workshops nos mais diversos locais, além de ter participado também do II e III Encontros Nacionais de Gestalt-Terapia. Foi consultor e supervisor de trabalhos em consultoria empresarial.

Nós, da abordagem Fenomenológico-Existencial da PUC-SP, tínhamos, por mais de uma década, reunião toda semana na casa onde ele tinha consultório. Eu chegava propositalmente mais cedo pois assim nos encontrávamos na cozinha e "papeávamos, trocando causos".

Quanta saudade...

ArI REHFELD - Psicoterapeuta, Coordenador do Abordagem Fenomenológico-Existencial da Faculdade de Psicologia da Pontifícia Universidade Católica de São Paulo (PUC-São Paulo); Precursor da Abordagem Fenomenológico-Existencial na Gestalt-Terapia brasileira. 